\title{
ALA Awards 1972
}

The following is a list of American Library Association awards for 1972. They are listed according to their classification as awards, citations, scholarships, and grants for special studies or projects. Each member of the Association is invited to nominate candidates.

ALA Goals Award. The J. Morris JonesWorld Book Encyclopedia-ALA Goals Award ( under the jurisdiction of the Executive Board) is an annual grant of $\$ 25,000$ made by the Field Enterprises Educational Corporation, Inc., to encourage and advance the development of public and/or school library service and librarianship through recognition and support of programs which implement Goals for Action adopted by the ALA Council. All applications for grants must be submitted to the executive director of ALA no later than February 14, 1972. The programs selected as award recipients will be announced at the 1972 ALA Annual Conference. Units of the Association eligible for grants under the award are ALA committees, ALA joint committees, ALA divisions, ALA round tables, and ALA chapters. Applications for grants from units within a division must be approved by the governing board of the division.

Clafence Day Award. An annual award, consisting of a citation, $\$ 1,000$, and a contemporary print. It is made to a librarian or to another individual who has, through substantial published work, such as a book, essay, or published lectures, promoted a love of books and reading, such work to have been published within the five calendar years preceding the presentation of the award. Donated by the Association of American Publishers. Administered by the ALA Awards Committee. Deadline for nominations is January 15, 1972. Send five copies of nominations to the jury chairman, William S. Dix, University Librarian, Princeton University Library, Princeton, NJ 08540. Staff liaison, Judith F. Krug.

Melvil Dewey Medal, An engraved medal and a citation presented annually to an individual or a group for recent creative professional achievement of a high order, particularly in those fields in which Melvil Dewey was actively interested, notably, library management, library training, cataloging and classification, and the tools and techniques of librarianship. Donated by the Forest Press, Inc. Administered by the ALA Awards Committee. Deadline for nominations is January 15, 1972. Send five copies of nominations to the jury chairman, Dr. Oliver T. Field, Associate Pro- fessor, Graduate School of Librarianship, University of Denver, University Park, Denver, CO 80210. Staff liaison, Judith F. Krug.

Library Buildings Award Program. An award established by the American Institute of Architects, the American Library Association, and the National Book Committee to encourage excellence in the architectural design and planning of libraries, to consist of a citation and a plaque to be placed in each winning building. Awards are made to all types of libraries. ALA participation authorized by Council in 1962 . Deadline for entry slips and fees was October 29, 1971. Deadline for submission of brochures and folders is December 31, 1971. Application forms are available from the Library Administration Division, ALA Headquarters. Staff liaison, Ruth F. Frame.

Joseph W. Lippincott AWARd. An award, consisting of $\$ 1,000$, an engraved medal, and a citation of achievement, presented annually to a librarian for distinguished service in the profession of librarianship, such service to include outstanding participation in the activities of professional library associations, notable published professional writing, or other significant activity in behalf of the profession and its aims. Donated by Joseph W. Lippincott. Administered by the ALA Awards Committee. Deadline for nominations is January 15, 1972. Five copies of nominations should be sent to the jury chairman, Wyman Jones, City Librarian, Los Angeles Public Library, 630 W. Fifth St., Los Angeles, CA 90017. Staff liaison, Judith F. Krug.

Eunice Rockwell Oberly Memorial Awards. A biennial award given in odd-numbered years, consisting of a citation and a cash award from the income of the Oberly Memorial Fund, presented to an American citizen who compiles the best bibliography in the field of agriculture or one of the related sciences in the two-year period preceding the year in which the award is made. The bibliographies are judged on accuracy, scope, usefulness, format, and special features such as explanatory introductions, annotations, and indexes. Made possible by a fund established by colleagues in memory of Eunice Rockwell Oberly. Administered by the Association of College \& Research Libraries, Agriculture and Biological Sciences Subsection. Deadline for nominations is March 15, 1973. Send nominations to the jury chairman, Charles Long, Libraries of Arnold Arboretum and Gray Herbarium, Harvard University, 22 Divinity Ave., Cambridge, MA 02138. Staff liaison, J. Donald Thomas. 
Scarecrow Press Award for Library LitERATURE. An award, consisting of $\$ 500$ and a citation, presented to an American librarian to recognize an outstanding contribution to library literature issued during the calendar year preceding the presentation. The award will be given only when a title merits such recognition. Donated by Scarecrow Press. Administered by ALA Awards Committee. The deadline for nominations is January 15, 1972. Send nominations to the jury chairman, Dr. Ray W. Frantz, Jr., University Librarian, University of Virginia, Alderman Library, Charlottesville, VA 22904. Staff liaison, Judith F. Krug.

H. W. Wilson Library Periodical Award. An annual award, consisting of $\$ 250$ and a certificate, presented to a periodical published by a local, state, or regional library, library group, or library association in the United States or Canada which has made an outstanding contribution to librarianship. (This excludes publications of ALA, CLA, and their divisions.) All issues for the calendar year prior to the presentation of the award will be judged on the basis of sustained excellence in both content and format, with consideration being given to both purpose and budget. The award is presented only in those years when a periodical merits such recognition. Donated by $H$. W. Wilson Company. Administered by the ALA Awards Committee. The deadline for nominations is January 15,1972 . Nominations in three copies should be sent to the jury chairman, Mrs. Kathleen Draper, Library Science Librarian, University of Illinois Library, Room 308 Library, Urbana, IL 61801. Staff liaison, Judith F. Krug.

Halsey W. Wilson Library Recruitment AWARD. An annual award, consisting of $\$ 1,000$, presented to any local, state, or regional library association, any library school, or any other appropriate group concerned with recruitment to the profession. (To be eligible, a state or regional library association must be a chapter of ALA.) The award is presented to the development of a sustained program of recruitment for librarianship and will be based on a total continuing program, not limited to one year's activity. The criteria upon which selection will be based are definition of goals; appropriateness and value to the library needs of the area in which the program is conducted; number of individuals entering library school or library employment; number and kind of individuals or groups reached; or other demonstrable results. The money comprising the award will be used for the continuation and further development of a recruitment program. There may be direct application or nomination for this award. Donated by the H. W. Wilson Company. Administered by the ALA Awards
Committee. The deadline for nominations is January 15, 1972. Send five copies of nominations to the jury chairman, Robert F. Ensley, Consultant, Illinois State Library, Centennial Building, Springfield, IL 62706. Staff liaison, Judith F. Krug.

Francis Joseph Campell Citation. An annual award, consisting of a citation and a medal, presented to a person who has made an outstanding contribution to the advancement of library service for the blind. This contribution may take the form of an imaginative and constructive program in a particular library; a recognized contribution to the national library program for blind persons; creative participation in library associations or blind organizations which advance reading for the blind; a significant publication or writing in the field; imaginative contribution to library administration, reference, circulation, selections, acquisitions, or technical services; or any activity of recognized importance. Donated and administered by the Round Table on Library Service to the Blind. The deadline for nominations is January 15, 1972. Nominations should be sent to the jury chairman, Mrs. Billie J. Ouellette, Perkins School for the Blind Library, Watertown, MA 02172. Staff liaison, Ira Phillips.

John Cotton Dana Public Relations Awards Contest. An annual citation made to libraries or library organizations of all types submitting scrapbooks representing the year's public relations program. Donated by the H. W. Wilson Company. Administered jointly by the Public Relations Section of the Library Administration Division and the Wilson $\mathrm{Li}$ brary Bulletin. Deadline for entries, March 27, 1972. Deadline for scrapbooks, April 10, 1972. Send entries and scrapbooks to John Cotton Dana Public Relations Awards Contest, c/o Wilson Library Bulletin, 950 University Ave., Bronx, NY 10452. Information available from jury chairman, Alan Kusler, Public Library, Rochester, NY 14601. Staff liaison, Ruth R. Frame.

Margahet Mann Citation. An annual citation made to a cataloger or classifier, not necessarily an American, for outstanding professional achievement in the areas of cataloging or classification, either through publication of significant professional literature, participating in professional cataloging association, introduction of new techniques of recognized importance, or outstanding work in the area of teaching within the past five years. Donated and administered by the Cataloging and Classification Section, Resources and Technical Services Division. Deadline for nominations, January 1,1972 . Send nominations with resume of achievement on which nomination is based to 
jury chairman, Emilie V. Wiggins, 2950 Newark St., N.W., Washington, DC 20008. Staff liaison, Mrs. Carol Raney Kelm.

Isadore Gilbert Mudge Citation. A citation to be given at the Annual Conference of the ALA to a person who has made a distinguished contribution to reference librarianship. This contribution may take the form of an imaginative and constructive program in a particular library; the writing of a significant book or articles in the reference field; creative and inspirational teaching of reference service; or other noteworthy activities which stimulate reference librarians to more distinguished performance. Donated and administered by the Reference Services Division. Deadline for nominations, March 15, 1972. Send nominations to jury chairman, Walter Allen, Graduate School of Library Science, University of Illinois, Urbana, IL 61801. Staff liaison, Andrew Hansen.

Esther J. Piercy Award. An annual citation presented in recognition of a contribution to librarianship in the field of the technical services by younger members of the profession. The recipient will be a librarian with not more than ten years of professional experience who has shown outstanding promise for continuing contributions and leadership in any of the fields comprising technical services by such means as: (a) leadership in professional associations at local, state, regional, or national levels; (b) contributions to the development, application, or utilization of new or improved methods, techniques, and routines; (c) a significant contribution to professional literature; (d) conduct of studies or research in the technical services. The award will be given each year in which the jury believes there is a qualified recipient. Donated and administered by the Resources and Technical Services Division. Deadline for nominations, January 1, 1972. Send nominations to jury chairman, Mrs. Roma S. Gregory, Head, Acquisitions Dept., University of Rochester, Rochester, NY 14627. Staff liaison, Mrs. Carol Raney Kelm.

ALA Scholarship Program. ALA Scholarship Program, approved by the ALA Council, January 1969, provides scholarships, in the amount of $\$ 2,500$, to be given annually to worthy students to begin and/or further their library education at the graduate level without regard to race, creed, color, or national origin. The recipients must enter a formal program of graduate study leading to a degree or advanced certificate at an ALA-accredited school. As many scholarships as possible will be awarded, depending upon the total amount of contributed funds. The award may be withheld in any year when there are no worthy recipients. Administered by ALA Awards Committee and the Library Education Division. Applications must be submitted by December 10, 1971. Application and recommendation forms are available from the jury chairman, J. Phillip Immroth, Graduate School of Library and Information Science, University of Pittsburgh, Pittsburgh, PA 15213. Staff liaison, Delores Vaughan.

Library Binding Institute Scholarship. An annual scholarship of $\$ 1,000$ made to a worthy student to further his library education. It is made to a resident of the United States without regard to race, color, creed, or geographical origin. Donated by the Library Binding Institute. Administered by the Library Education Division. Applications must be submitted by January 10, 1972. Information and application forms are available from the jury chairman, Martin Cohen, School of Librarianship, Western Michigan University, Kalamazoo, MI 49001. Staff liaison, Delores Vaughan.

Exhibits Round TABLE. An annual award of $\$ 500$ made to an individual or a group to aid or improve some particular aspect of librarianship or library service on the basis of need in the profession or in the operation of professional library associations. Donated and administered by the Exhibits Round Table. Chairman: To be appointed. Nominations should be forwarded before the ALA conference to the staff liaison, Chris Hoy.

Herbert W. Putnam Honor Fund Award. An award of $\$ 500$ presented at intervals as a grant-in-aid to an American librarian of outstanding ability for travel, writing, or other use that might improve his or her service to the library profession or to society. Administered by the ALA Awards Committee which serves as the jury. Nominations should be sent to Robert F. Delzell, Director of Personnel, University of Illinois Library, Urbana, IL 61801. Staff liaison, Judith F. Krug.

The chairman of the ALA Awards Committee is Robert F. Delzell, Director of Personnel, University of Illinois Library, Urbana, IL 6180I.

\section{ACQUIRE RARE MANUSCRIPT}

A facsimile of the New Testament portion of Codex Vaticanus, one of the most important ancient manuscripts of the Vatican Library, has been presented to the DuKe UNIVErsity library as a gift from Pope Paul VI. The presentation of the copy of this fourth-century manuscript was made by Dr. Howard Wilkinson to university librarian Benjamin E. Powell in a special ceremony in the Rare Book Room, Perkins Library, on September 24, 1971, at which Dr. Kenneth Clark, professor emeritus, and Father Roland Murphy, professor of old Testament of the Duke Divinity School, spoke about the significance of the manuscript. 